\title{
Effect of exposure to sublethal concentrations of sodium cyanide on the carbohydrate metabolism of the Indian Major Carp Labeo rohita (Hamilton, 1822) ${ }^{1}$
}

\author{
Praveen N. Dube ${ }^{2}$, Shwetha Alavandi ${ }^{2}$ and Basaling B. Hosetti ${ }^{2 *}$
}

\begin{abstract}
Dube P.N., Alavandi S. \& Hosetti B.B. 2013. Effect of exposure to sublethal concentrations of sodium cyanide on the carbohydrate metabolism of the Indian Major Carp Labeo rohita (Hamilton, 1822). Pesquisa Veterinária Brasileira 33(7):914-919. Toxicology Laboratory, Department of Applied Zoology, School of Biological Sciences, Jnana Sahyadri, Shankaraghatta, Shimoga, Karnataka 577 451, India. E-mail: basaling@yahoo.co.in

Experiments were designed to study in-vivo effects of sodium cyanide on biochemical endpoints in the freshwater fish Labeo rohita. Fish were exposed to two sublethal concentrations $(0.106$ and $0.064 \mathrm{mg} / \mathrm{L})$ for a period of 15 days. Levels of glycogen, pyruvate, lactate and the enzymatic activities of lactate dehydrogenase (LDH), succinate dehydrogenase (SDH), glucose-6-phosphate dehydrogenase (G6PDH), phosphorylase, alkaline phosphatase (ALP), acid phosphatase (AcP) were assessed in different tissues (liver, muscle and gills). Result indicated a steady decrease in glycogen, pyruvate, SDH, ALP and AcP activity with a concomitant increase in the lactate, phosphorylase, LDH and G6PD activity in all selected tissues. The alterations in all the above biochemical parameters were significantly $(p<0.05)$ time and dose dependent. In all the above parameters, liver pointing out the intensity of cyanide intoxication compare to muscle and gills. Study revealed change in the metabolic energy by means of altered metabolic profile of the fish. Further, these observations indicated that even sublethal concentrations of sodium cyanide might not be fully devoid of deleterious influence on metabolism in L. rohita.
\end{abstract}

INDEX TERMS: Labeo rohita, metabolism, oxidative enzymes, sodium cyanide, subacute.

\section{INTRODUCTION}

Cyanide is a well known chemical for its properties as suicidal, homicidal and chemical warfare agent (Hariharakrishnan et al. 2010). Industries dealing with metal plating and finishing, mining and extraction of metals such as gold and silver, production of synthetic fibers and the processing of coal generate large quantities of cyanide-containing wastes (Rocha-e-Silva et al. 2010). Consequently release of cyanide containing wastes into the environment has generated considerable interest. Cyanide is found to be highly toxic to the aquatic organisms, primarily due to the formation of complexes with metal ions that are present as enzyme cofactors. Most notably this occurs with $\mathrm{Fe}^{3+}$ ion in cytochrome, thereby inhibiting respiration and hence, oxidative

\footnotetext{
${ }^{1}$ Received on March 1, 2012.

Accepted for publication on September 10, 2012.

${ }^{2}$ Toxicology Laboratory, Department of Applied Zoology, School of Biological Sciences, Jnana Sahyadri, Shankaraghatta, Shimoga, Karnataka 577 451, India. *Corresponding author: basaling@yahoo.co.in
}

phosphorylation (Daya et al. 2000). Lower concentrations in the range of $50-100 \mu \mathrm{g} / \mathrm{l}$ of cyanide have proven eventually fatal to many sensitive fish species (Dube \& Hosetti 2010). Even at concentrations as low as $20 \mu \mathrm{g} / \mathrm{l}$, chronic or sublethal effects of cyanide have been found in several freshwater species (Heath 1991).

Biochemical alterations are considered as sensitive indicators of toxicity before hazardous effects occur in fish. Biochemical approach has been advocated to provide an early warning of potentially harmful changes in stressed fish. Evaluation of intermediary metabolism of fish was used, for example, to study cyanide induced effects (Prashanth \& Neelgund 2007, De Zwaan et al. 1993). The effect of toxicant on enzymatic activity is one of the most important biochemical parameters, which is affected under stress (Das \& Mukherjee 2003). When an organ is diseased due to the effect of a toxicant, enzymatic activity appears to be increased or inhibited due to the active site being either denatured or distorted. Since some enzymes catalyze some steps in the metabolism of carbohydrate and protein, 
they are present in most tissues. The increase or decrease in their level may be sufficient to provide information of diagnostic values (Begum 2009).

Sodium cyanide is extremely toxic, which might hamper the fish health through the impairment in the metabolism, sometimes leading to death. This is because, most of the cyanide absorbed is detoxified by enzymatic combination with sulfur, and thus the detoxification process imposes a nutritional cost (Prashanth \& Neelagund 2007). Concentrations of cyanides and lethal and sublethal toxicities of cyanides to the fishes are well documented (Dube \& Hosetti 2010). Further it is also essential to evaluate the sublethal effects of cyanides on the fishes, since they form very important members of the food chain. Consequently it was considered as a matter of warranted interest to elucidate biochemical effects in the fish. Evaluation of biochemical activities in an organism helps to identify disturbances in its metabolism. In this study, we monitored the disturbances of metabolism in Labeo rohita by exposing them to different sublethal concentrations of sodium cyanide for a period of 15 days. Labeo rohita constitutes one of the main fish species of economic importance, as an abundant cultural fish species in India and as very popular fish among farmers and consumers.

\section{MATERIALS AND METHODS}

Studies were conducted on fingerlings of Labeo rohita, obtained from State Fisheries Department, Bhadra Reservoir Project (BRP), Shimoga, Karnataka, India. Fish weighing 3.5 $\pm 0.5 \mathrm{~g}$ with mean body length $6 \pm 0.75 \mathrm{~cm}$ were maintained in large holding tanks following standard fish maintenance procedure during acclimatization and exposure (APHA 2005). Acclimatized fishes were transferred to aquaria (20 L) for subacute studies. Aquarium water was kept oxygen saturated by aeration and its temperature was maintained at ambient laboratory temperature $\left(25 \pm 1^{\circ} \mathrm{C}\right)$. Animals were transferred to a fresh volume of water for every 24 $\mathrm{h}$ to minimize contamination from metabolic wastes and the fishes were fed with fish food pellets (Nova Aquatic Pvt Ltd, not less than $3 \%$ of body weight). Prior to exposure the fish were examined carefully for any pathological symptoms.

Stock solution of the sodium cyanide (99.9\%, Loba Chemicals Mumbai, Maharashtra, India) was prepared in double distilled water. After acclimatization, fish were transferred to aquarium (20 L capacity) supplied with dechlorinated tap water (total hardness $23.4 \pm 3.4 \mathrm{mg}$ as $\mathrm{CaCO}_{3} / \mathrm{L}$, phosphate $0.39 \pm 0.002 \mu \mathrm{g} / \mathrm{L}$, salinity $0.01 \mathrm{ppt}$, specific gravity 1.001 and conductivity less than $10 \mu \mathrm{S} / \mathrm{cm})$. Experiments were carried out in static renewal system (APHA 2005). Median lethal concentration ( $96 \mathrm{~h} \mathrm{LC}_{50}$ ) of sodium cyanide to L. rohita was found out to be $0.32 \mathrm{mg} / \mathrm{L}$ (Dube and Hosetti 2010). Two sublethal concentrations selected for the present study were based on the $1 / 3^{\text {rd }}$ and $1 / 5^{\text {th }}$ of the $96 \mathrm{~h} \mathrm{LC}_{50}$. Acclimatized fish were distributed into seven equal groups with ten fish each. Fish in first three groups were exposed to $0.106 \mathrm{mg} / \mathrm{L}$ and the next three groups to $0.064 \mathrm{mg} / \mathrm{L}$ of sodium cyanide, while remaining group was kept in cyanide free tap water, served as control. Five replicas were maintained for each concentration. The test media was changed daily with fresh addition of toxicant.

At the end of 5, 10 and 15 days of exposure, fish were sacrificed and liver, gill, muscle tissues were collected immediately, washed with distilled water and weighed before homogenization. Tissues were homogenized using a glass homogenizer with respective homogenizer solution and centrifuged. Glycogen content in the tissue was estimated by using the anthrone reagent as described by Caroll et al (1956). The homogenate (5\%) was prepared in 5\% trichloroacetic acid (TCA). Values were expressed as mg glycogen/g of tissue. Pyruvate level was measured according to Friedman \& Haugen (1943). Homogenate $(50 \mathrm{mg} / \mathrm{ml})$ was prepared in $10 \%$ TCA. Sodium pyruvate was taken as standard and the values were expressed as mg pyruvate/g tissue. Lactate content in the tissues was estimated according to the method of Huckabee (1961). Homogenate $(50 \mathrm{mg} / \mathrm{ml}$,) was prepared in $10 \%$ cold TCA and centrifuged at $1000 \mathrm{~g}$ for 5 minutes. Sodium lactate was taken as standard. Lactate content was expressed as mg lactate/g wet weight tissue. LDH (EC 1.1.1.27) was assayed following Govindappa \& Swami (1965) and SDH (EC 1.3.99.1) by the method of Nachilas et al (1960). The formazon extracted was measured at $495 \mathrm{~nm}$ and the activity of enzyme was represented in $\mu \mathrm{mol}$ formazon/mg of tissue. For the estimation of G6PDH (EC 1.1.49) activity method described by Bergmeyer \& Bernt (1965) and Glycogen phosphorylase activity (EC 2.4.1.1.), using; the method described by Sutherland (1955) was followed and the activity expressed as $\mu \mathrm{M}$ Pi liberated/mg protein/h, using phosphate standards. Acid Phosphatase (AcP; E.C. 3.1.3.2) in the tissues were estimated by using method of Kind \& King (1954) and the inorganic phosphate (Pi) liberated was measured by the method of Fiske \& Subbarow (1925). The enzyme assays were made after preliminary standardization regarding linearly with respect to time of incubation of enzyme concentration. Enzyme activity was expressed as $\mu \mathrm{mol} \mathrm{Pi}$ liberated/mg protein/h.

Each assay was replicated five times, and values thus obtained were converted to percentage of the respective control and analysis of variance (ANOVA) was employed followed by Duncan multiple range test as post hoc as test to calculate the significant difference. The analysis was made between the means of the control and cyanide treated fishes. In all the cases, differences were considered statistically significant at $p<0.05$ (Daniel 1987).

\section{RESULTS AND DISCUSSION}

No mortality was observed during in the fish exposed to both sublethal concentrations of sodium cyanide. The effect of cyanide in the liver, muscle and gills of Labeo rohita are shown in Table 1 to 4 . The biochemical changes observed in the present study were due to disturbed metabolism in the fish. Cyanide has its own target sites of action and most of them are metabolic depressors. They generally affect the activity of biologically active molecules (Prashanth \& Neelagund 2007).

\section{Effect on glycogen}

Glycogen level in all the three tissues significantly declined in both concentrations. The percent in the glycogen content in the fish exposed to $0.106 \mathrm{mg} / \mathrm{L}$ of sodium cyanide ranged from liver (19.49 to $37.10 \%)>$ muscle (19.45 to $34.93 \%$ ) > gills (11.37 to $31.43 \%$ ), whereas at $0.064 \mathrm{mg} / \mathrm{L}$, liver $(12.97$ to $31.89 \%)>$ muscle ( 13.53 to $31.24 \%$ ) > gills (8.83 to $24.71 \%$ ). Maximum decrease was observed in the liver tissues in $1 / 3^{\text {rd }}$ sublethal concentration (Table 1 ). Significant decrease which was dose depended may be considered to be symptom of stress induced by cyanide. Marked glycogenolysis was observed after subacute exposure to sodium cyanide. Glycogen breakdown is known to be rapidly activated as a result of changes in both extracellular and intracellular environments. Massive glycogenolysis has been reported to occur due to shortfall of oxygen in the tissues 
Table 1. Effect of sublethal concentrations of sodium cyanide on glycogen, pyruvate and lactate levels in different tissues of Labeo rohita

\begin{tabular}{|c|c|c|c|c|c|c|c|}
\hline \multirow{2}{*}{\multicolumn{2}{|c|}{ Control }} & \multicolumn{3}{|c|}{$0.106 \mathrm{mg} / \mathrm{L}$} & \multicolumn{3}{|c|}{$0.064 \mathrm{mg} / \mathrm{L}$} \\
\hline & & 5 & 10 & 15 & 5 & 10 & 15 \\
\hline \multicolumn{8}{|c|}{ Glycogen (mg / g wet wt) } \\
\hline Liver & $7.20 \pm 0.47^{\mathrm{a}}$ & $5.79 \pm 0.34^{\mathrm{c}}$ & $5.11 \pm 0.22^{\mathrm{e}}$ & $4.53 \pm 0.65^{g}$ & $6.26 \pm 0.11^{b}$ & $5.50 \pm 0.32^{\mathrm{d}}$ & $4.90 \pm 0.18^{f}$ \\
\hline Muscle & $1.84 \pm 0.41^{\mathrm{a}}$ & $1.36 \pm 0.23^{\mathrm{e}}$ & $1.48 \pm 0.16^{\mathrm{c}}$ & $1.20 \pm 0.26^{\mathrm{g}}$ & $1.59 \pm 0.23^{b}$ & $1.37 \pm 0.74^{\mathrm{d}}$ & $1.27 \pm 0.52^{\mathrm{f}}$ \\
\hline Gill & $1.73 \pm 0.12^{\mathrm{a}}$ & $1.53 \pm 0.37^{c}$ & $1.34 \pm 0.12^{\mathrm{e}}$ & $1.18 \pm 0.32^{\mathrm{g}}$ & $1.57 \pm 0.54^{\mathrm{b}}$ & $1.42 \pm 0.18^{\mathrm{d}}$ & $1.30 \pm 0.65^{f}$ \\
\hline \multicolumn{8}{|c|}{ Pyruvate (mg / g wet wt) } \\
\hline Liver & $12.73 \pm 0.43^{a}$ & $11.22 \pm 0.32^{\mathrm{c}}$ & $10.11 \pm 0.67^{\mathrm{e}}$ & $7.54 \pm 0.54^{\mathrm{g}}$ & $10.39 \pm 0.44^{\mathrm{d}}$ & $11.45 \pm 0.68^{\mathbf{b}}$ & $8.92 \pm 0.84^{\mathrm{f}}$ \\
\hline Muscle & $9.66 \pm 0.32^{\mathrm{a}}$ & $8.13 \pm 0.65^{c}$ & $7.45 \pm 0.34^{\mathrm{e}}$ & $6.13 \pm 0.22^{\mathrm{g}}$ & $8.95 \pm 0.54^{\mathrm{b}}$ & $6.85 \pm 0.87^{f}$ & $7.90 \pm 0.22^{\mathrm{d}}$ \\
\hline Gill & $10.24 \pm 0.78^{a}$ & $8.65 \pm 0.44^{\mathrm{e}}$ & $9.26 \pm 0.93^{c}$ & $7.27 \pm 0.42^{\mathrm{g}}$ & $9.33 \pm 0.65^{b}$ & $8.76 \pm 0.65^{d}$ & $7.95 \pm 0.12^{f}$ \\
\hline \multicolumn{8}{|c|}{ Lactate (mg / g wet wt) } \\
\hline Liver & $2.55 \pm 0.32^{\mathrm{g}}$ & $3.22 \pm 0.54^{\mathrm{d}}$ & $3.55 \pm 0.31^{\mathrm{a}}$ & $3.35 \pm 0.37^{c}$ & $2.95 \pm 0.38^{\mathrm{f}}$ & $3.18 \pm 0.24^{\mathrm{e}}$ & $3.43 \pm 0.13^{\mathrm{b}}$ \\
\hline Muscle & $3.47 \pm 0.34^{\mathrm{g}}$ & $3.84 \pm 0.62^{\mathrm{e}}$ & $4.23 \pm 0.41^{\mathrm{d}}$ & $5.18 \pm 0.21^{\mathrm{a}}$ & $3.77 \pm 0.64^{\mathrm{f}}$ & $4.64 \pm 0.13^{c}$ & $4.94 \pm 0.53^{\mathrm{b}}$ \\
\hline Gill & $2.55 \pm 0.42^{\mathrm{g}}$ & $3.11 \pm 0.51^{\mathrm{e}}$ & $3.36 \pm 0.43^{b}$ & $3.62 \pm 0.17^{\mathrm{a}}$ & $2.96 \pm 0.62^{f}$ & $3.28 \pm 0.43^{\mathrm{d}}$ & $3.32 \pm 0.73^{\mathrm{c}}$ \\
\hline
\end{tabular}

Data are means $\pm S D(n=5)$ for an organ in a row followed by the same letter are significantly different $(p<0.05)$ from each other according to Duncan's multiple range test.

(Rees et al. 2009). The decrease was greater in liver than in muscle and gills, since liver is the principal organ for glycogen storage. Depletion of glycogen may also indicate its direct utilization for energy generation, a demand caused by cyanide-induced hypoxia (Dube \& Hosetti 2010).

\section{Effect on pyruvate}

Table 1 show pyruvate levels in all the three tissues. Maximum decrease was recorded in the liver and lowest in the muscle. The percent decrease in the pyruvate content in different tissues was in the order of liver (11.91 to $40.76 \%)>$ muscle $(15.83$ to $36.58 \%)>$ gill $(9.55$ to $28.98 \%$ ) in $0.106 \mathrm{mg} / \mathrm{L}$ of sodium cyanide and liver $(10.07$ to $29.92 \%$ ) > muscle (7.34 to $29.03 \%$ ) > gill (8.85 to $22.33 \%$ ) in $0.064 \mathrm{mg} / \mathrm{L}$ of sodium cyanide. Decrease in the level of pyruvate suggests the possibility of a shift towards anaerobic dependence due to a remarkable drop in aerobic segment, a characteristic feature of cyanide intoxication (Singh et al. 1989). This might also be due to its conversion to lactate, or due to its mobilization to form amino acids, lipids, triglycerides and glycogen synthesis in addition to its role as a detoxification (De Zwaan et al. 1993).

\section{Effect on lactate}

Lactate concentrations reached highest values after subacute exposure compared to control (Table 1). Significantly elevated lactate concentrations were observed in the fishes exposed to cyanide. Values ranged from muscle (10.57 to $48.96 \%$ ) > gills (22.45 to $42.69 \%$ ) >l iver (26.21 to $39.39 \%$ ) in $0.106 \mathrm{mg} / \mathrm{L}$ and in $0.064 \mathrm{mg} / \mathrm{L}$ sodium cyanide, muscle (8.54 to $42.03 \%$ ) > liver (15.95 to $34.59 \%$ ) > gills (16.21 to $30.13 \%)$. The level of lactic acid in the tissue known to act as an index of anaerobiosis (Rees et al. 2009), which might be beneficial to the animal to tolerate hypoxic conditions (Baud et al. 2002). Observed changes in the lactate level, which was dose depended, may be considered as a symptom of stress induced by the cyanide. Similar observations were noticed in the rats following exposure to cyanide and carbon monoxide (Dodds et al. 1992).

\section{Effect on LDH and SDH}

In contrast to control, significant inhibition in the activity of SDH and enhancement of LDH levels were noticed at both the concentrations (Table 2). The activity levels scored high in liver than the muscles and gills. The LDH activity was in the range of liver (23.27 to $44.16 \%)>$ gill (13.79 to $43.34 \%$ ) > muscle (15.19 to $40.13 \%$ ) at $0.106 \mathrm{mg} / \mathrm{L}$ and in $0.064 \mathrm{mg} / \mathrm{L}$ of sodium cyanide, gill (9.09 to $36.58 \%$ ) > muscle (12.55 to $33.22 \%$ ) > liver (14.71 to $33.06 \%$ ). Similarly, SDH activity ranged in liver (16. 12 to $40.32 \%$ ) > muscle (9.83 to $39.88 \%$ ) > gill ( 16.45 to $39.62 \%$ ) in 0.106 $\mathrm{mg} / \mathrm{L}$ and in $0.064 \mathrm{mg} / \mathrm{L}$ of sodium cyanide, gill (10.65 to $30.70 \%)>$ liver $(13.09$ to $30.08 \%$ ) > muscle $(7.11$ to $29.57 \%$ ) respectively. Any change in the intermediary me-

Table 2. Effect of sublethal concentrations of sodium cyanide on activities of LDH and SDH in different tissues of Labeo rohita

\begin{tabular}{|c|c|c|c|c|c|c|c|}
\hline \multirow{2}{*}{\multicolumn{2}{|c|}{ Control }} & \multicolumn{3}{|c|}{$0.106 \mathrm{mg} / \mathrm{L}$} & \multicolumn{3}{|c|}{$0.064 \mathrm{mg} / \mathrm{L}$} \\
\hline & & 5 & 10 & 15 & 5 & 10 & 15 \\
\hline \multicolumn{8}{|c|}{ LDH (mM formazon/mg protein/h) } \\
\hline Liver & $5.23 \pm 0.44^{\mathrm{g}}$ & $6.45 \pm 0.34^{\mathrm{e}}$ & $6.94 \pm 0.64^{\mathrm{c}}$ & $7.54 \pm 0.35^{\mathrm{a}}$ & $5.98 \pm 0.32^{f}$ & $6.51 \pm 0.44^{\mathrm{d}}$ & $6.96 \pm 0.44^{\mathrm{b}}$ \\
\hline Muscle & $4.02 \pm 0.65^{\mathrm{g}}$ & $4.63 \pm 0.44^{\mathrm{e}}$ & $4.96 \pm 0.33^{\mathrm{c}}$ & $5.64 \pm 0.41^{\mathrm{a}}$ & $4.53 \pm 0.22^{\mathrm{f}}$ & $4.80 \pm 0.43^{\mathrm{d}}$ & $5.36 \pm 0.65^{\mathrm{b}}$ \\
\hline Gill & $3.64 \pm 0.44^{\mathrm{g}}$ & $4.14 \pm 0.31^{\mathrm{e}}$ & $4.53 \pm 0.24^{c}$ & $5.22 \pm 0.11^{\mathrm{a}}$ & $3.97 \pm 0.85^{f}$ & $4.33 \pm 0.77^{\mathrm{d}}$ & $4.97 \pm 0.93^{b}$ \\
\hline \multicolumn{8}{|c|}{ SDH (mM formazon/mg protein/h) } \\
\hline Liver & $3.62 \pm 0.23^{\mathrm{a}}$ & $3.04 \pm 0.87^{\mathrm{c}}$ & $2.74 \pm 0.27^{\mathrm{e}}$ & $2.16 \pm 0.87^{\mathrm{g}}$ & $3.15 \pm 0.47^{\mathrm{b}}$ & $2.85 \pm 0.31^{\mathrm{d}}$ & $2.53 \pm 0.62^{\mathrm{f}}$ \\
\hline Muscle & $1.58 \pm 0.62^{\mathrm{a}}$ & $1.43 \pm 0.98^{\mathrm{c}}$ & $1.25 \pm 0.86^{\mathrm{e}}$ & $0.95 \pm 0.34^{\mathrm{g}}$ & $1.47 \pm 0.11^{\mathrm{b}}$ & $1.38 \pm 0.60^{\mathrm{d}}$ & $1.11 \pm 0.72^{\mathrm{f}}$ \\
\hline Gill & $0.86 \pm 0.62^{\mathrm{a}}$ & $0.72 \pm 0.46^{\mathrm{c}}$ & $0.65 \pm 0.13^{\mathrm{e}}$ & $0.52 \pm 0.87^{\mathrm{g}}$ & $0.76 \pm 0.62^{\mathrm{b}}$ & $0.59 \pm 0.45^{f}$ & $0.68 \pm 0.11^{\mathrm{d}}$ \\
\hline
\end{tabular}

Data are means \pm SD $(n=5)$ for an organ in a row followed by the same letter are sig nificantly different $(p<0.05)$ from each other according to Duncan's multiple range test 
tabolism due to stress is results in altered activity of oxidative enzymes like SDH, LDH, and G6PDH. These may also contribute to the classic signs of cyanide toxicity (Baud et al. 2002). Stimulation of LDH and concurrent inhibition of $\mathrm{SDH}$, in the tissues of the cyanide-intoxicated fish signifies disturbances in the cellular oxidative processes (Daya et al. 2000). The changes appear to favor alternative metabolism in response to the environmental stress, probably due to the inability of the tissues of fish to derive sufficient oxygen for the normal metabolic functions. Increased LDH resulted in lactic acidosis, due to an enhanced rate of conversion of pyruvate to lactate (Singh et al. 1989, Rees et al. 2009). Similarly under hypoxic condition augmented release of LDH in to the tissues were reported by Sharma \& Jain (2008). The significant decline of LDH activity in L. rohita further suggest the decrease in the glycolytic process due to the lower metabolic rate as a result of cyanide exposure (Bhattacharya et al. 2009). The suppression of SDH activity in subacute conditions indicates derailment of metabolic cycle. This may also be due to the mitochondrial disruption leading to a decrease in activities of oxidative enzymes. The induced decrease of SDH activity can be attributed to the ability of cyanide to inhibit mitochondrial enzymatic activities (Archanakumta \& Gaikwad 1998). Ramkritinan et al (2005) reported similar results in the fish Cyprinus carpio exposed to distillery effluents.

\section{Effect on G6PDH}

Glucose-6-Phosphate dehydrogenase (G6PDH), key enzyme that catalyses the oxidative irreversible step PPP (Pentose phosphate pathway) exhibited enhanced activity under cyanide intoxication (Table 3 ). Activity ranged from liver (21.92 to $49.42 \%$ ) > gills (16.93 to $41.63 \%$ ) > muscle (18.77 to $37.79 \%)$ in $1 / 3^{\text {rd }}$ and at $1 / 5^{\text {th }}$ sublethal concentration, liver (15.72 to $42.93 \%$ ) > muscle (16.18 to $34.49 \%$ ) > gills (13.61 to $33.46 \%$ ) respectively. G6PDH is mainly regulated by the NADPH/NADP ratio (Saraswathi \& Govindasamy 2002), needed as reducing power for various detoxification pathways. The effects of different chemical substances on the activity of G6PDH enzyme have been investigated in many in vitro and in vivo studies, performed with various organisms (Murat et al. 2009). In the present study, sodium cyanide significantly stimulated G6PDH activity in the fish indicating mobilization of glucose through pathways other than glycolysis-Krebs cycle. High G6PDH activity is indicative of increase in the HMP (Hexose monophosphate) shunt under stress condition. Since G6PDH can generate $\mathrm{NAD}^{+}$rapidly, thereby promoting triose phosphate oxidation which is found to increase during the stress. Similar results were reported by Surendranath et al (1991) and substantiate the present work.

\section{Effect on glycogen phosphorylase}

Decrease in the levels of glycogen was accompanied by an increase in the activity of phosphorylase, main glycogen degrading enzyme (Table 3 ). The activity ranged from liver (20.01 to $39.41 \%)>$ muscle (9.65 to $21.95 \%)>$ gill $(6.75$ to $20.11 \%$ ) in $1 / 3^{\text {rd }}$ and at $1 / 5^{\text {th }}$ sublethal concentration muscle $(6.45$ to $19.40 \%)>$ liver $(11.54$ to $13.71 \%)>$ gill (2.13 to $12.31 \%$ ). Augmentation of phosphorylase activity in tissues of the cyanide exposed fish indicates the active breakdown of glycogen. Therefore the observed decrease in the glycogen content of the tissues with concurrent increased efficiency of phosphorylase following exposure to sodium cyanide may be a compensatory mechanism to meet the increased energy demand. Anoxia or malfunction of the respiratory chain could induce the generation of a stimulator of phosphorylase activity (Begum 2009). Hypoxic conditions in tissues have been reported to increase the catalytic efficiency of phosphorylase (Conaglen et al. 1984). The glycogenolytic rate in hypoxic conditions is about two fold higher than expected from the concentration of the normal phosphorylase (Vandebroeck et al. 1988).

\section{Effect on acid and alkaline phosphatase}

Exposure to sodium cyanide induced significant decline in phosphatase activity (Table 4) in the fish. Activity of AcP, ranged from liver (19.06 to $38.21 \%$ ) > muscle (15.66 to $32.66 \%)>$ gill $(13.88$ to $25.64 \%)$ at $1 / 3^{\text {rd }}$ and at $1 / 5^{\text {th }}$ sublethal concentration liver (22.91 to $35.57 \%)>$ muscle (17.61 to $29.84 \%)>$ gill (13.68 to $23.17 \%$ ). Similarly for ALP, the activity ranged from liver (20.14 to $33.49 \%$ ) > muscle (14.81 to $28.36 \%)>$ gill $(12.69$ to $25.40 \%)$ at $1 / 3^{\text {rd }}$ and at $1 / 5^{\text {th }}$ sublethal concentration liver (20.48 to $\left.29.72 \%\right)>$ muscle ( 15.87 to $25.28 \%$ ) > gill (15.54 to $23.28 \%$ ) respectively. The significant difference in phosphatases activities between the control and experimental groups of fish may be due to the damage of hepatic tissue with disturbed normal liver function. Since, cyanide has anti-phosphatase activity; inhibition of phosphatase activity may be due to

Table 3. Effect of sublethal concentrations of sodium cyanide on activities of G6PDH and glycogen phosphorylase in different tissues of Labeo rohita

\begin{tabular}{|c|c|c|c|c|c|c|c|}
\hline & \multirow[t]{2}{*}{ Control } & \multicolumn{3}{|c|}{$0.106 \mathrm{mg} / \mathrm{L}$} & \multicolumn{3}{|c|}{$0.064 \mathrm{mg} / \mathrm{L}$} \\
\hline & & 5 & 10 & 15 & 5 & 10 & 15 \\
\hline \multicolumn{8}{|c|}{ G6PDH (mM of Pi formed/mg protein/h) } \\
\hline Liver & $5.34 \pm 0.44^{\mathrm{g}}$ & $6.52 \pm 0.15^{\mathrm{e}}$ & $7.12 \pm 0.54^{\mathrm{c}}$ & $7.99 \pm 0.32^{\mathrm{a}}$ & $6.18 \pm 0.35^{f}$ & $6.95 \pm 0.12^{\mathrm{d}}$ & $7.64 \pm 0.31^{\mathrm{b}}$ \\
\hline Muscle & $7.53 \pm 0.25^{\mathrm{g}}$ & $8.94 \pm 0.14^{\mathrm{e}}$ & $10.38 \pm 0.19^{a}$ & $9.82 \pm 0.28^{c}$ & $8.75 \pm 0.34^{f}$ & $10.13 \pm 0.29^{b}$ & $9.65 \pm 0.53^{d}$ \\
\hline Gill & $2.95 \pm 0.22^{\mathrm{g}}$ & $3.45 \pm 0.16^{\mathrm{e}}$ & $3.81 \pm 0.33^{c}$ & $4.18 \pm 0.21^{\mathrm{a}}$ & $3.35 \pm 0.28^{f}$ & $3.63 \pm 0.63^{d}$ & $3.94 \pm 0.72^{b}$ \\
\hline \multicolumn{8}{|c|}{ Glycogen phosphorylase (mM of Pi formed/mg protein/h) } \\
\hline Liver & $7.83 \pm 0.01^{\mathrm{a}}$ & $9.40 \pm 0.08^{c}$ & $10.26 \pm 0.01^{\mathrm{e}}$ & $10.91 \pm 0.02^{\mathrm{a}}$ & $6.13 \pm 0.05^{\mathrm{g}}$ & $5.94 \pm 0.08^{g}$ & $5.56 \pm 0.01^{\mathrm{g}}$ \\
\hline Muscle & $4.87 \pm 0.06^{\mathrm{a}}$ & $5.58 \pm 0.08^{c}$ & $5.34 \pm 0.05^{\mathrm{e}}$ & $5.94 \pm 0.04 \mathrm{~g}$ & $5.19 \pm 0.13^{\mathrm{g}}$ & $5.51 \pm 0.01^{\mathrm{g}}$ & $5.82 \pm 0.02^{\mathrm{g}}$ \\
\hline Gill & $1.42 \pm 0.03^{\mathrm{a}}$ & $1.52 \pm 0.15^{\mathrm{c}}$ & $1.71 \pm 0.01^{\mathrm{e}}$ & $1.63 \pm 0.10^{\mathrm{g}}$ & $1.45 \pm 0.01^{\mathrm{g}}$ & $1.54 \pm 0.04^{\mathrm{g}}$ & $1.59 \pm 0.02^{\mathrm{g}}$ \\
\hline
\end{tabular}

$\overline{\text { Data are means } \pm} \mathrm{SD}(\mathrm{n}=5)$ for an organ in a row followed by the same letter are significantly different $(\mathrm{p}<0.05)$ from each other according to Duncan's multiple range test. 
Table 4. Effect of sublethal concentrations of sodium cyanide on acid and alkaline phosphatase activities in different tissues of Labeo rohita

\begin{tabular}{|c|c|c|c|c|c|c|c|}
\hline & \multirow[t]{2}{*}{ Control } & \multicolumn{3}{|c|}{$0.106 \mathrm{mg} / \mathrm{L}$} & \multicolumn{3}{|c|}{$0.064 \mathrm{mg} / \mathrm{L}$} \\
\hline & & 5 & 10 & 15 & 5 & 10 & 15 \\
\hline \multicolumn{8}{|c|}{ AcP (mM of p-nitro phenol formed/mg protein/h) } \\
\hline Liver & $13.52 \pm 0.54^{\mathrm{a}}$ & $10.95 \pm 0.76^{\mathrm{b}}$ & $9.27 \pm 0.65^{\mathrm{d}}$ & $8.36 \pm 0.54^{\mathrm{g}}$ & $10.43 \pm 0.65^{c}$ & $8.71 \pm 0.32^{\mathrm{f}}$ & $9.25 \pm 0.43^{\mathrm{e}}$ \\
\hline Muscle & $8.94 \pm 0.45^{\mathrm{a}}$ & $6.76 \pm 0.27^{\mathrm{d}}$ & $7.54 \pm 0.48^{\mathrm{b}}$ & $6.02 \pm 0.38^{\mathrm{g}}$ & $7.37 \pm 0.70^{\mathrm{c}}$ & $6.57 \pm 0.24^{\mathrm{e}}$ & $6.27 \pm 0.12^{\mathrm{f}}$ \\
\hline Gill & $7.15 \pm 0.98^{\mathrm{a}}$ & $6.16 \pm 0.54^{\mathrm{c}}$ & $5.81 \pm 0.63^{e}$ & $5.32 \pm 0.34^{\mathrm{g}}$ & $5.85 \pm 0.89^{d}$ & $6.17 \pm 0.43^{b}$ & $5.50 \pm 0.37^{\mathrm{f}}$ \\
\hline \multicolumn{8}{|c|}{ ALP (mM of p-nitro phenol formed/mg protein $/ \mathrm{h}$ ) } \\
\hline Liver & $24.74 \pm 0.54^{\mathrm{a}}$ & $18.56 \pm 0.62^{\mathrm{e}}$ & $19.76 \pm 0.26^{\mathbf{b}}$ & $16.45 \pm 0.87^{g}$ & $19.67 \pm 0.38^{c}$ & $18.25 \pm 0.18^{f}$ & $17.39 \pm 0.41^{\mathrm{d}}$ \\
\hline Muscle & $21.96 \pm 0.76^{\mathrm{a}}$ & $18.71 \pm 0.16^{\mathbf{b}}$ & $17.26 \pm 0.16^{\mathrm{d}}$ & $15.73 \pm 0.72^{\mathrm{g}}$ & $18.25 \pm 0.23^{c}$ & $16.41 \pm 0.76^{\mathrm{f}}$ & $16.93 \pm 0.59^{\mathrm{e}}$ \\
\hline Gill & $15.26 \pm 0.23^{a}$ & $13.32 \pm 0.98^{b}$ & $11.38 \pm 0.49^{g}$ & $12.30 \pm 0.51^{\mathrm{d}}$ & $12.88 \pm 0.43^{c}$ & $11.93 \pm 0.65^{e}$ & $11.70 \pm 0.13^{\mathrm{f}}$ \\
\hline
\end{tabular}

Data are means $\pm S D(n=5)$ for an organ in a row followed by the same letter are significantly different $(\mathrm{p}<0.05)$ from each other according to Duncan's multiple range test.

reduced protein synthesis, as such phosphatases plays an important role in protein synthesis (Okolie \& Osagie 2000). Ogundele et al (2010) illustrated inhibition in ALP and AcP activity in the adult Wistar rats, administered with the cassava. Inyang et al (2011) reported inhibition of ALP and AcP activity in the fish Clarias gariepinus resulting from the Diazinon exposure. Das \& Mukharjee (2003) made similar observation in the fish Labeo rohita exposed to sublethal concentrations of cypermethrin. Due to the resulting activity of AcP and ALP activity, it may be assumed that the liver tissue of the experimental animal exhibited marked inhibition in the activity of phosphatases by cyanide. As hypoxic cell damages are mediated through increased permeability of cell membrane, the localization of phosphatases within the membrane would make it highly susceptible to release in cyanide-induced tissue lesions (Rees et al. 2009). This may be responsible for the inhibition of phosphatases in the tissue of the cyanide-intoxicated animals.

\section{CONCLUSION}

The results of this study show clearly that carbohydrate metabolism in the fish disrupted in the presence of the sodium cyanide, and this may lead to a severe energy crisis at the cellular level and altered the intermediary metabolism. Decreased activity of SDH, with concomitant increase in the LDH, G6PDH and phosphorylase in various tissues under cyanide intoxication indicates the switch over of metabolic pathways towards compensatory mechanisms. This clearly represents a shift from aerobic to anaerobic metabolism as evidenced by elevated lactate and fall in pyruvate levels. Therefore, alterations in the metabolism of the fish reflects the differential effects of stress and can be considered as a biomonitoring tool in the assessment of environmental pollution by cyanide on non-target organisms.

Acknowledgments.- The authors wish to thank the State Fishery Department, BR Project, Shimoga, Karnataka, India, for their timely supplying of the fish fingerlings. The authors wish to express their gratitude to the University Grant Commission, New Delhi, for financial support in the form of a Major Research Project (F.No.34-459/2008 SR) and also to Kuvempu University for providing necessary infrastructural facilities to carry out the experiments.

\section{REFERENCES}

APHA 2005. Standard methods for the examination of water and wastewater. $21^{\text {st }}$ ed. American Public Health Association (APHA), American
Water Works Association (AWWA) and Water Environment Federation (WEF). Washington, DC.

Archanakumta A. \& Gaikwad S.A. 1998. Effect of nitrite on succinate dehydrogenase (LDH) and lactate dehydrogenase (LDH) in the freshwater fish Gambusia affinis. Poll. Res.17:177-179.

Baud F.J., Borron S.W., Mégarbane B., Trout H.D., Lapostolle F., Vicaut E., Debray M. \& Bismuth C. 2002. Value of lactic acidosis in the assessment of the severity of acute cyanide poisoning. Crit. Care. Med. 30(9):20442050.

Begum G. 2009. Enzymes as biomarkers of cypermethrin toxicity: response of Clarias batrachus tissues ATPase and glycogen phosphorylase as a function of exposure and recovery at sublethal level. Toxicol. Mech. Methods. 19(1):29-39.

Bergmeyer H.U. \& Bernt E. 1965. In: Bergmeyer H.U. (Ed.), Methods of Enzymatic Analysis. Academic Press, New York.

Bhattacharya R., Satpute R.M., Hariharakrishnan J., Tripathi H. \& Saxena P. B. 2009. Acute toxicity of some synthetic cyanogens in rats and their response to oral treatment with alpha-ketoglutarate. Food. Chem. Toxicol. 47: 2314-2320.

Caroll N.V., Longley R.W. \& Row J.H. 1956. Glycogen determination in liver and muscle by use of anthrone reagent. J. Biol. Chem. 22: 583-594.

Conaglen J.V., Malthus R.S., Redshaw-Loten J.C. \& Sheyd J.G.T. 1984. The action of anion and cyanide on glycogen breakdown in the liver of grd/ grd rat. Eur. J. Biochem. 145:323.

Daniel W.W. 1987. Biostatistics: A foundation for analysis in the health sciences. $4^{\text {th }}$ ed. Wiley, New York, p.276-296.

Das B.K. \& Mukherjee S.C. 2003. Toxicity of cypermethrin in Labeo rohita fingerlings: Biochemical enzymatic and hematological consequences. Comp. Biochem. Physiol. Toxicol. Pharmacol. 137:325-333.

Daya S., Walker R.B. \& Dukie S.A. 2000. Cyanide induced free radical production and lipid peroxidation in rat brain homogenate is reduced by aspirin. Metab. Brain. Dis. 5(3):203-210.

De Zwaan A., Cattan O. \& Putzer V.M. 1993. Sulfide and cyanide induced mortality and anaerobic metabolism in the arcid blood clam Scapharca inaequiv alvis. Comp. Biochem. Physiol. C. Comp. Pharmacol. 105(1): 49-54.

Dodds R.G., Penney D.G. \& Sutariya B.B. 1992. Cardiovascular, metabolic and neurologic effects of carbon monoxide and cyanide in the rat. Toxicol. Lett. 61: 243-254.

Dube P.N. \& Hosetti B.B. 2010. Assessment of acute toxicity of sodium cyanide to a freshwater teleost, Labeo rohita (Ham). Online. J. Vet. Res. 14 (2):176-187.

Fiske C. \& Subbarow Y. 1925. The colorimetric determination of phosphorus. J. Biol. Chem. 66:375-400.

Friedman T.E. \& Haugen G.F. 1943. Pyruvic acid I. Collection of blood for the determination of pyruvic acid and lactic acid. J. Biol. Chem. 144:6777.

Govindappa S. \& Swami K.S. 1965. Electrophoretic characteristics of sub cellular compounds and their relation to enzyme activities in amphibian muscle. Ind. J. Environ. Biol. 10 (4):349-353. 
Hariharakrishnan J., Satpute R.M. \& Bhattacharya R. 2010. Cyanide induced changes in the levels of neurotransmitters in discrete brain regions of rats and their response to oral treatment with $\alpha$-ketoglutarate. Ind. J. Exp. Biol. 48:731-736.

Heath A.G. 1991. Water Pollution and Fish Physiology. Lewis Publishers, Boca, Ranton, Florida.

Huckabee W.E. 1961. Relationship of pyruvate and lactate during anaerobic metabolism. V. Corouary adequacy. Ann. J. Physiol. 200(6):1169-1179.

Inyang I.R., Daka E.R. \& Ogamba E.N. 2011. Effect of Diazinon on Acid and Alkaline Phosphatase Activities in Plasma and Organs of Clarias gariepinus. Curr. Res. J. Biol. Sci. 3(3):191-194.

Kind P.N.R. \& King E.J. 1954. In vitro determination of serum alkaline phosphatase. J. Clin. Pathol. 7:322.

Murat S., Saltuk B.C., Orhan E. \& Ömer I.K. 2009. In vitro and in vivo effects of some pesticides on glucose-6-phosphate dehydrogenase enzyme activity from rainbow trout (Oncorhynchus mykiss) erythrocytes. Pestic. Biochem. Phys. 95: 95-99.

Nachilas M.M., Marguiles S.P. \& Serigman A.M. 1960. A Calorimetric method for determination of succinate dehydrogenase activity. J. Biol. Chem. 235:490-503.

Ogundele O.M., Caxton-Martins E.A., Ghazal O.K. \& Jimoh O.R. 2010. Neurotoxicity of cassava: Mode of cell death in the visual relay centres of adult Wistar rats. J. Cell. Anim. Biol. 4(8):119-124.

Okolie N.P. \& Osagie A.U. 2000. Differential effects of chronic cyanide intoxication on heart, lung and pancreatic tissues. Food. Chem. Toxicol. 38(6):543-548.

Prashanth M.S. \& Neelgund S.E. 2007. Free cyanide-induced Biochemical changes in Nitrogen metabolism of the Indian major carp, Cirrhinus mrigala. J. Basic Clin. Physiol. Pharmacol. 8(4):77-287.
Ramkritinan C.M., Kumaraguru A.K. \& Balasubramanian M.P. 2005. Impact of distillery effluents on carbohydrate metabolism of freshwater fish, Cyprinus carpio. J. Fish. Biol. 14:693.

Rees B.B., Boily P. \& Williamson L.A.C. 2009. Exercise- and hypoxia-induced anaerobic metabolism and recovery: a student laboratory exercise using teleost fish. Adv. Physiol. Educ. 33:72-77.

Rocha-e-Silva R.C., Cordeiro L.A.V. \& Soto-Blanco B. 2010. Cyanide toxicity and interference with diet selection in quail (Coturnix coturnix). Comp. Biochem. Physiol. Part C. 151:294-297.

Saraswathi P.R. \& Govindasamy S. 2002. Effect of sodium molybdate on carbohydrate metabolizing enzymes in alloxan induced diabetic rats. J. Nutr. Biochem. 13:21-26

Sharma M. \& Jain K.L. 2008. Alteration in the metabolic enzyme activity of muscle tissues in the fish Cyprinus carpio (L) on chronic exposure to some pesticides. J. Aqua. 16: 7-12.

Singh B.M., Coles N., Lewis P., Braithwaite R.A., Nattrass M. \& FitzGerald M.G. 1989. The metabolic effects of fatal cyanide poisoning. Postgrad. Med. J. 65:923-925.

Surendranath P., Ghouselazam S. \& Rama Rao K.V. 1991. Significance of glucose-6-phosphate dehydrogenase activity in the tissues of penaeid prawn, Metapenaeus monoceros (Fabricius) under acute kelthane exposure. Bull. Environ. Contam. Toxicol. 56:738-744.

Sutherland E.W. 1955. Polysaccharide phosphorylase, liver, p.215-225. In: Colowick S.P. \& Kaplan N.O. (Eds), Methods in Enzymology. Vol.I. Academic Press, New York.

Vandebroeck A., Uyttenhove K., Bollen M. \& Stalmans W. 1988. The hepatic glycogenolysis induced by reversible ischaemia or KCN is exclusively catalysed by phosphorylase a. Biochem. J. 256:685-688. 